\title{
Synergistic effects of zirconium- and aluminum co-doping on the thermoelectric performance of zinc oxide
}

Kiryl V. Zakharchuk ${ }^{a}$, David M. Tobaldi ${ }^{a}$, Xingxing Xiao ${ }^{\text {b }}$, Wenjie Xie ${ }^{\text {b }}$, Sergey M. Mikhalev

c, João F. Martins ${ }^{\text {a }}$, Jorge R. Frade ${ }^{\text {a }}$, Anke Weidenkaff ${ }^{\mathrm{b}}$, Andrei V. Kovalevsky*a

a CICECO - Aveiro Institute of Materials, Department of Materials and Ceramic Engineering, University of Aveiro, 3810-193 Aveiro, Portugal;

b Materials Chemistry, Institute for Materials Science, University of Stuttgart, Heisenbergstr. 3, DE-70569 Stuttgart, Germany;

c TEMA-NRD, Mechanical Engineering Department, Aveiro Institute of Nanotechnology (AIN), University of Aveiro, 3810-193 Aveiro, Portugal;

* Corresponding author. Present address: Department of Materials and Ceramic Engineering, CICECO - Aveiro Institute of Materials, University of Aveiro, 3810-193 Aveiro, Portugal.

Fax: +351-234-370204; Tel: +351-234-370235; E-mail: akavaleuski@ua.pt 


\begin{abstract}
This work aims to explore zirconium as a possible dopant to promote thermoelectric performance in bulk $\mathrm{ZnO}$-based materials, both within the single-doping concept and on simultaneous codoping with aluminum. At 1100-1223 K mixed-doped samples demonstrated around 2.3 times increase in ZT as compared to single-doped materials, reaching $\sim 0.12$. The simultaneous presence of aluminum and zirconium imposes a synergistic effect on electrical properties provided by their mutual effects on the solubility in $\mathrm{ZnO}$ crystal lattice, while also allowing a moderate decrease of the thermal conductivity due to phonon scattering effects. At $1173 \mathrm{~K}$ the power factor of mixeddoped $\mathrm{Zn}_{0.994} \mathrm{Al}_{0.003} \mathrm{Zr}_{0.003} \mathrm{O}$ was 2.2-2.5 times higher than for single-doped materials. Stability tests of the prepared materials under prospective operation conditions indicated that the gradual increase in both resistivity and Seebeck coefficient in mixed-doped compositions with time may partially compensate each other to maintain a relatively high power factor.
\end{abstract}

Keywords: zinc oxide, thermoelectric performance, electrical properties, thermal conductivity, zirconium doping 


\section{Introduction}

Thermoelectric (TE) conversion of waste or solar heat into electricity represents a promising solution to meet growing needs in low-carbon and energy-efficient technologies [1-3]. The efficiency of thermoelectric generation is limited by the Carnot efficiency and characterized by the figure of merit $Z T=\alpha^{2} T / \rho \kappa$, combining Seebeck coefficient $(\alpha)$, electrical resistivity $(\rho)$, thermal conductivity $(\kappa)$ of the candidate materials, and working temperature $(T)$. Prospective applications require the thermoelectric materials with high thermal and chemical stability, the absence of toxicity and high natural abundance of the constituent elements. These represent the main advantages of oxide-based TE materials over traditional, $\mathrm{Bi}_{2} \mathrm{Te}_{3}, \mathrm{Bi}_{2} \mathrm{Se}_{3}, \mathrm{PbTe}$-based thermoelectrics. Yet, ZT values obtained for the best-known oxide thermoelectrics are much lower than those required by most potential applications [4].

TE oxides arrived at a turning point when good TE properties were reported for $\mathrm{NaCo}_{2} \mathrm{O}_{4}$ in 1997 [5]. In the last two decades, more than an order of magnitude enhancement in ZT of oxides was achieved [6,7]. While being rather known for promising optoelectronic, catalytic and photochemical properties [8,9], donor-doped zinc oxide $(\mathrm{ZnO})$ was also considered as a potential high-temperature thermoelectric material [10,11]. Doping with elements capable to possess the oxidation states higher than $2+$ is a known straightforward approach to tune TE performance of ZnO. Representative examples include aluminum [10-13], indium [14-16], iron [17], nickel [18], bismuth [15,19], etc. From those, aluminum can be considered as a most used and common dopant. The co-doping strategy was also found fairly effective [20-23]. In particular, the ZT values of AlGa-, and Al-Ni- co-doped $\mathrm{ZnO}$ materials reach up to $0.47-0.65$ at $1173-1243 \mathrm{~K}$, being among the highest observed so far in oxide-based thermoelectrics [20,21]. This behavior was attributed to the microstructural evolution in co-doped ceramics, leading to a decrease in the thermal conductivity while maintaining an appropriate electrical performance. Another interesting effect of co-doping, leading to an enhancement of aluminum solubility due to the presence of nickel cations and a 
corresponding increase in the charge carrier concentration was demonstrated for $\mathrm{Zn}(\mathrm{Al}, \mathrm{Ni}) \mathrm{O}$ $[22,23]$.

Although fourfold coordinated $\mathrm{Zr}^{4+}$ has an ionic radius comparable with that of $\mathrm{Zn}^{2+}$ and is expected to be an efficient electron donor due to high charge, to our best knowledge, zirconium was not yet assessed as a dopant to enhance the thermoelectric performance of bulk ZnO-based materials. Structural and electrical properties of Zr-doped zinc oxides were studied aiming mainly transparent conducting oxide thin films with improved optical and electrical properties [24-26]. Thus, the present work aims to assess the prospects for boosting TE performance of ZnO-based materials through zirconia addition, both within single-doping and co-doping concepts. For the latter, aluminum was selected as a second dopant, based on relatively well-studied thermoelectric properties and related effects in $\mathrm{Zn}(\mathrm{Al}) \mathrm{O}$ system. Particular attention was given to the assessment of the stability at high temperatures, where degradation of the electrical properties represents one of the main obstacles towards the potential application of $\mathrm{ZnO}$-based thermoelectrics [27,28].

\section{Experimental}

The set of nominal sample compositions prepared in the present work included single-

doped $\quad \mathrm{Zn}_{0.997} \mathrm{Al}_{0.003} \mathrm{O}, \quad \mathrm{Zn}_{0.993} \mathrm{Al}_{0.007} \mathrm{O}, \quad \mathrm{Zn}_{0.997} \mathrm{Zr}_{0.003} \mathrm{O}, \quad \mathrm{Zn}_{0.993} \mathrm{Zr}_{0.007} \mathrm{O}, \quad$ mixed-doped $\mathrm{Zn}_{0.993} \mathrm{Al}_{0.002} \mathrm{Zr}_{0.005} \mathrm{O}, \mathrm{Zn}_{0.994} \mathrm{Al}_{0.003} \mathrm{Zr}_{0.003} \mathrm{O}$ and $\mathrm{Zn}_{0.993} \mathrm{Al}_{0.005} \mathrm{Zr}_{0.002} \mathrm{O}$, and $\mathrm{ZnO}$ reference sample. The materials were prepared using a conventional solid state route starting from $\mathrm{ZnO}$ (Alfa-Aesar, 99.99\%), $\mathrm{Al}_{2} \mathrm{O}_{3}$ (Sigma-Aldrich, 99.7\%) and Tosoh grade $\mathrm{ZrO}_{2}$ powders. Multiple annealing steps at $1173-1373 \mathrm{~K}$ for 5-15 $\mathrm{h}$ with intermediate regrindings were conducted. After subsequent ballmilling with ethanol, drying, preliminary uniaxial and final isostatic compacting at $200 \mathrm{MPa}$, the corresponding ceramics were sintered at $1773 \mathrm{~K}$ for $5 \mathrm{~h}$ in air. 
X-Ray diffraction (XRD), differential scanning calorimetry (DSC) and diffuse reflectance spectroscopy (DRS) studies were performed on fine powders, prepared by grinding the sintered ceramic samples. Both polished and thermally-etched, and freshly-fractured ceramics were characterized by scanning electron microscopy combined with energy dispersive spectroscopy (SEM/EDS). For the combined total conductivity and Seebeck coefficient measurements the sintered ceramics were cut into rectangular bars $\sim 1.5 \times 2.5 \times 15 \mathrm{~mm}^{3}$. Thermal diffusivity studies were performed on $\sim 1.00 \mathrm{~mm}$ thick disc-shaped ceramic samples.

XRD patterns were recorded at room temperature using a PANalytical X'Pert PRO diffractometer $(\mathrm{CuK} \alpha)$ and scanning in the range $2 \Theta=10^{\circ}-80^{\circ}$, with a step of $0.02^{\circ}$ and an exposition time of $200 \mathrm{~s}$. SEM (Hitachi SU-70 instrument) and EDS (Bruker Quantax 400 detector) equipment were used for the microstructural characterization of the polished and fractured ceramics. The optical band gap $\left(E_{g}\right)$ of the powdered samples, obtained by grinding of the sintered ceramics, was assessed by DRS using a Shimadzu UV 3100 (JP) spectrometer, equipped with an integrating sphere and a white reference material, made of $\mathrm{BaSO}_{4}$ and Spectralon ${ }^{\circledR}$, respectively. The spectra of the samples were acquired in the UV-Vis range $(250-825 \mathrm{~nm})$, with $0.2 \mathrm{~nm}$ step size.

The total electrical conductivity $(\sigma)$ and Seebeck coefficient $(\alpha)$ were measured using an experimental setup described elsewhere [29]. The measurements were performed simultaneously in flowing air on stepwise cooling from $1223 \mathrm{~K}$ to $523 \mathrm{~K}$, followed by up to 0.5 hour thermal equilibration at each temperature, or vs. time in isothermal conditions. Good ohmic contacts for electrical characterization of $\mathrm{ZnO}$-based materials at low temperatures may represent a certain problem [30]; therefore, in several cases, the electrical conductivity data was extrapolated down to $380 \mathrm{~K}$ to obtain estimates for the lattice thermal conductivity. The estimated experimental error in measured values did not exceed $3-5 \%$ for $\sigma$ and $5-7 \%$ for $\alpha$. Similar thermal equilibration procedures were implemented for the thermal diffusivity $(D)$ and specific heat capacity $\left(C_{p}\right)$ 
studies, using a Netzsch LFA 457 Microflash and a Netzsch DSC 404F1 equipment, correspondingly. The thermal conductivity $(\kappa)$ was calculated as $\kappa=D \rho_{\exp } c_{\mathrm{p}}$, where $\rho_{\exp }$ is the sample density, calculated from the geometrical dimensions and weight of the disk-shaped sample. The estimated error of the obtained thermal conductivity values was less than $10 \%$.

\section{Results and discussion}

Representative room-temperature XRD patterns of the prepared materials are shown in Fig. 1.



Fig. 1. XRD patterns of the powdered $\mathrm{Zn}_{1-\mathrm{x}-\mathrm{y}} \mathrm{Al}_{\mathrm{x}} \mathrm{Zr}_{\mathrm{y}} \mathrm{O}$ samples.

All indexed reflections belong to a hexagonal wurtzite structure, indexed in accordance with ICDD reference pattern 04-009-7657. Based on the XRD results, all prepared materials are apparently single-phase, except for the $\mathrm{Zn}_{0.993} \mathrm{Zr}_{0.007} \mathrm{O}$ sample containing a detectable amount of the monoclinic $\mathrm{ZrO}_{2}$ phase (ICDD reference pattern 04-008-7682). The corresponding peak at $2 \Theta \sim 28.2^{\circ}$ is hardly visible for $\mathrm{Zn}_{0.993} \mathrm{Al}_{0.002} \mathrm{Zr}_{0.005} \mathrm{O}$ composition, however, suggesting that this 
impurity may also be present albeit in a lower amount. Table 1 lists the unit cell volumes for all prepared materials, calculated from the lattice parameters estimated using a profile matching method in Fullprof software [31]. Although aluminum incorporation into $\mathrm{ZnO}$ lattice was studied in many works, unambiguous identification of the relevant defect types and their effects on the lattice parameters is still debatable [32][33][34].

Table 1

Unit cell volume, experimental density and room-temperature optical band gap of $\mathrm{Zn}_{1-\mathrm{x}-\mathrm{y}} \mathrm{Al}_{\mathrm{x}} \mathrm{Zr}_{\mathrm{y}} \mathrm{O}$ samples

\begin{tabular}{|c|c|c|c|c|}
\hline Composition & $\begin{array}{c}\text { Unit cell volume } \\
V_{u c} \times 10^{3}, \mathrm{~nm}^{3}\end{array}$ & $\begin{array}{c}\text { Density } \rho_{\text {exp }} \\
( \pm 0.03), \\
\mathrm{g} / \mathrm{cm}^{3}\end{array}$ & $\begin{array}{c}\rho_{\text {exp }} / \rho_{\text {theor }} *, \\
\%\end{array}$ & $\begin{array}{c}E_{g}( \pm 0.01), \\
\mathrm{eV}\end{array}$ \\
\hline $\mathrm{ZnO}$ & $47.65(1)$ & 5.60 & 97.7 & 3.14 \\
\hline $\mathrm{Zn}_{0.997} \mathrm{Al}_{0.003} \mathrm{O}$ & $47.63(7)$ & 4.86 & 86.3 & 3.24 \\
\hline $\mathrm{Zn}_{0.993} \mathrm{Al}_{0.007} \mathrm{O}$ & $47.63(7)$ & 5.07 & 88.6 & - \\
\hline $\mathrm{Zn}_{0.997} \mathrm{Zr}_{0.003} \mathrm{O}$ & $47.66(0)$ & 5.15 & 96.2 & 3.23 \\
\hline $\mathrm{Zn}_{0.993} \mathrm{Zr}_{0.007} \mathrm{O}$ & $47.67(0)$ & 4.95 & 88.6 & - \\
\hline $\mathrm{Zn}_{0.993} \mathrm{Al}_{0.002} \mathrm{Zr}_{0.005} \mathrm{O}$ & $47.61(3)$ & 5.36 & 93.4 & 3.24 \\
\hline $\mathrm{Zn}_{0.994} \mathrm{Al}_{0.003} \mathrm{Zr}_{0.003} \mathrm{O}$ & $47.64(7)$ & 5.47 & 95.4 & 3.20 \\
\hline $\mathrm{Zn}_{0.993} \mathrm{Al}_{0.005} \mathrm{Zr}_{0.002} \mathrm{O}$ & $47.61(7)$ & 5.07 & 88.5 & 3.25 \\
\hline
\end{tabular}

* - the theoretical density was calculated from the XRD data assuming the phase-pure composition

Presence of fourfold-coordinated $\mathrm{Al}^{3+}$ substitution for $\mathrm{Zn}^{2+}$ is expected to decrease the unit cell volume, in agreement with the ionic radii listed by Shannon [35] and literature data (e.g., [33]). This is the case for both $\mathrm{Zn}_{0.997} \mathrm{Al}_{0.003} \mathrm{O}$ and $\mathrm{Zn}_{0.993} \mathrm{Al}_{0.007} \mathrm{O}$ compositions (Table 1). Nearly equal unit cell volumes of $\mathrm{Zn}_{0.997} \mathrm{Al}_{0.003} \mathrm{O}$ and $\mathrm{Zn}_{0.993} \mathrm{Al}_{0.007} \mathrm{O}$, however, indicate that for the selected processing conditions the mechanism of aluminum incorporation is altered on increasing its content. The latter may involve the formation of octahedrally and tetrahedrally-coordinated interstitial aluminum cations, core-shell structures with inhomogeneous $\mathrm{Al}$ content and a minor amount of side phases like $\mathrm{ZnAl}_{2} \mathrm{O}_{4}$ spinel ([32] and references therein). Furthermore, an increase 
in the lattice parameters was pointed out in [33], due to the occupation of the interstitial sites by $\mathrm{Al}$ atoms at high dopant contents

In accordance with the literature data, the lattice parameters of wurtzite phase in $\mathrm{ZnO}: \mathrm{Zr}$ thin films and $\mathrm{Zr}$-containing $\mathrm{ZnO}$ nanoparticles are increasing on zirconium content [24-26,36]. A similar tendency is also observed for the bulk $\mathrm{Zn}_{0.997} \mathrm{Zr}_{0.003} \mathrm{O}$ and $\mathrm{Zn}_{0.993} \mathrm{Zr}_{0.007} \mathrm{O}$ ceramics in the present work (Table 1). The ionic radius of fourfold-coordinated $\mathrm{Zr}^{4+}(0.59 \AA)$ is very close to that of $\mathrm{Zn}^{2+}(0.6 \AA)$; hence, the lattice expansion on doping likely originates from the lattice stresses promoted by excessive charge of $\mathrm{Zr}^{4+}$ cations and/or incorporation of zirconium in the interstitial positions with a higher coordination number [26]. The rather interesting case is represented by the mixed-doped compositions showing the unit cell volume notably below that for undoped $\mathrm{ZnO}$ (Table 2). This might be considered as a fingerprint of more complex defect structure, guided by a compromise between presumably different affinities of $\mathrm{Al}^{3+}$ and $\mathrm{Zr}^{4+}$ to reside in the lattice and interstitial sites with various coordination environments. Importantly, the tendencies for lattice expansion expected on doping with zirconium contradict to the experimental results (Table 1), especially in the case of mixed-doped $\mathrm{Zn}_{0.993} \mathrm{Al}_{0.002} \mathrm{Zr}_{0.005} \mathrm{O}$ and $\mathrm{Zn}_{0.993} \mathrm{Al}_{0.005} \mathrm{Zr}_{0.002} \mathrm{O}$ samples. A plausible explanation may be based on the assumption that the presence of zirconium species somehow facilitates aluminum incorporation into the lattice by substituting $\mathrm{Zn}^{2+}$ cations in tetrahedral coordination. The excessive charge of the $Z r_{Z n}^{\ddot{n}}$ point defects might introduce a local lattice stress and promote lattice expansion, which can be, to a certain extent, compensated by the presence of smaller $\mathrm{Al}^{3+}$ cations in tetrahedral coordination, along with the formation of cation vacancies $V_{Z n}^{\prime \prime}[32,34]$. For given processing conditions, such a compensation mechanism may increase the solubility of aluminum in zinc oxide lattice, resulting in an overall decrease of the unit cell volume. This hypothesis correlates with the studies of the microstructural and transport properties, as discussed below. 
Representative SEM micrographs of the fractured and polished ceramic samples are shown in Fig. 2. The applied processing conditions result in quite dense ceramics, as also evidenced by the density values given in Table 1 . Still, possible porosity effects on the electrical resistivity and the thermal conductivity were accounted using a Maxwell correction for homogeneouslydistributed spherical pores [12,37]. All materials possess similar grain size, with slightly smaller grains in the case of $\mathrm{Zr}$-containing samples, in agreement with [24]. Although the $\mathrm{Zn}_{0.993} \mathrm{Al}_{0.002} \mathrm{Zr}_{0.005} \mathrm{O}$ sample was apparently single-phase from the XRD results, the microstructural studies clearly indicate the presence of $\mathrm{ZrO}_{2}$ inclusions, further confirmed by EDS, similar to that observed for $\mathrm{Zn}_{0.993} \mathrm{Zr}_{0.007} \mathrm{O}$ composition (Fig. 2).
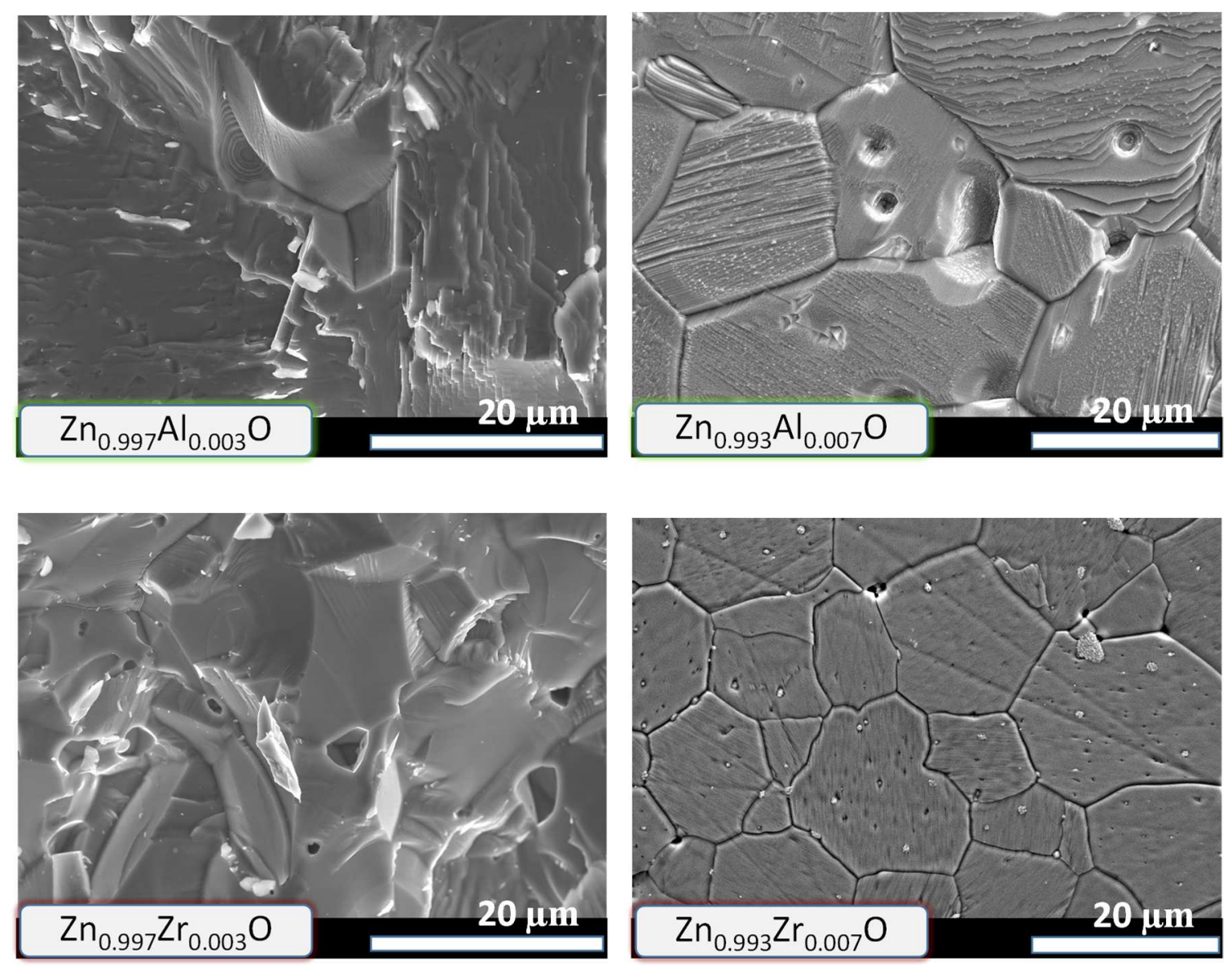

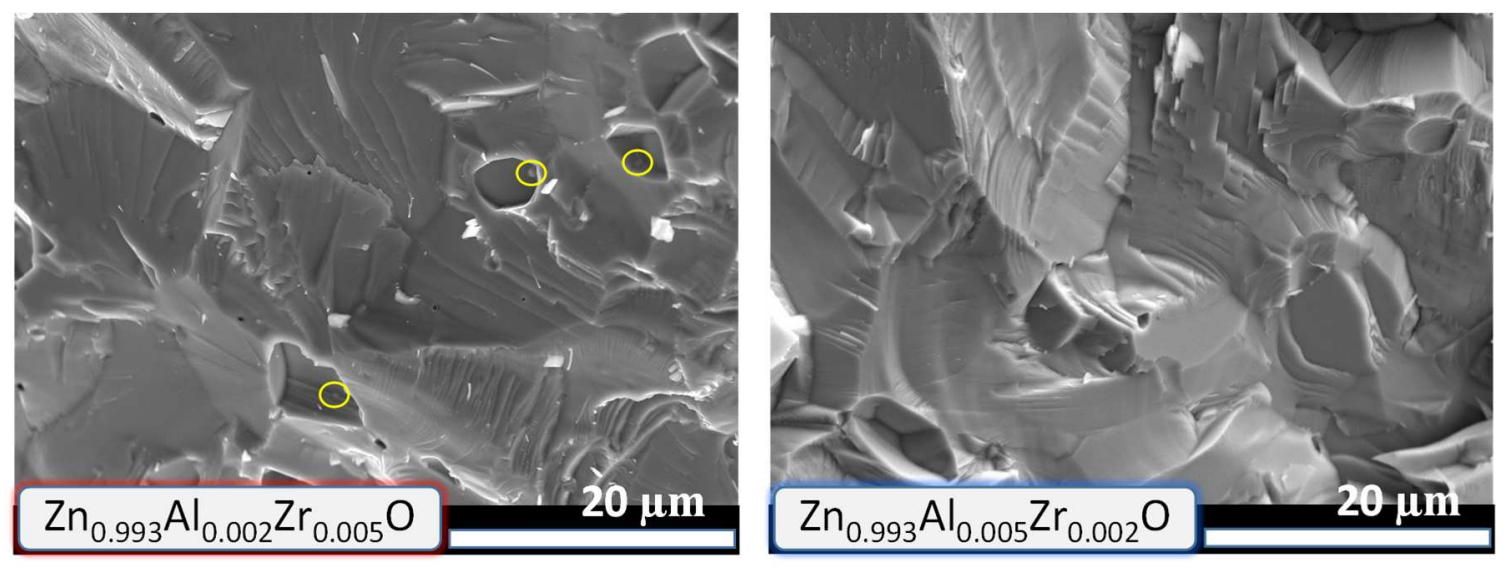

Fig. 2. SEM micrographs of the fractured and polished sintered $\mathrm{Zn}_{1-\mathrm{x}-\mathrm{y}} \mathrm{Al}_{\mathrm{x}} \mathrm{Zr}_{\mathrm{y}} \mathrm{O}$ ceramics. $\mathrm{ZrO}_{2}$ phase impurities in $\mathrm{Zn}_{0.993} \mathrm{Al}_{0.002} \mathrm{Zr}_{0.005} \mathrm{O}$ are marked by yellow ovals.

Detailed SEM inspection of the fractured $\mathrm{Zn}_{0.997} \mathrm{Al}_{0.003} \mathrm{O}$ sample did not reveal the presence of any impurities in the grains and grain boundaries, a representative SEM image and EDS maps of zinc and aluminum taken near the contact of two grains are shown in Fig. 3 (A-C).
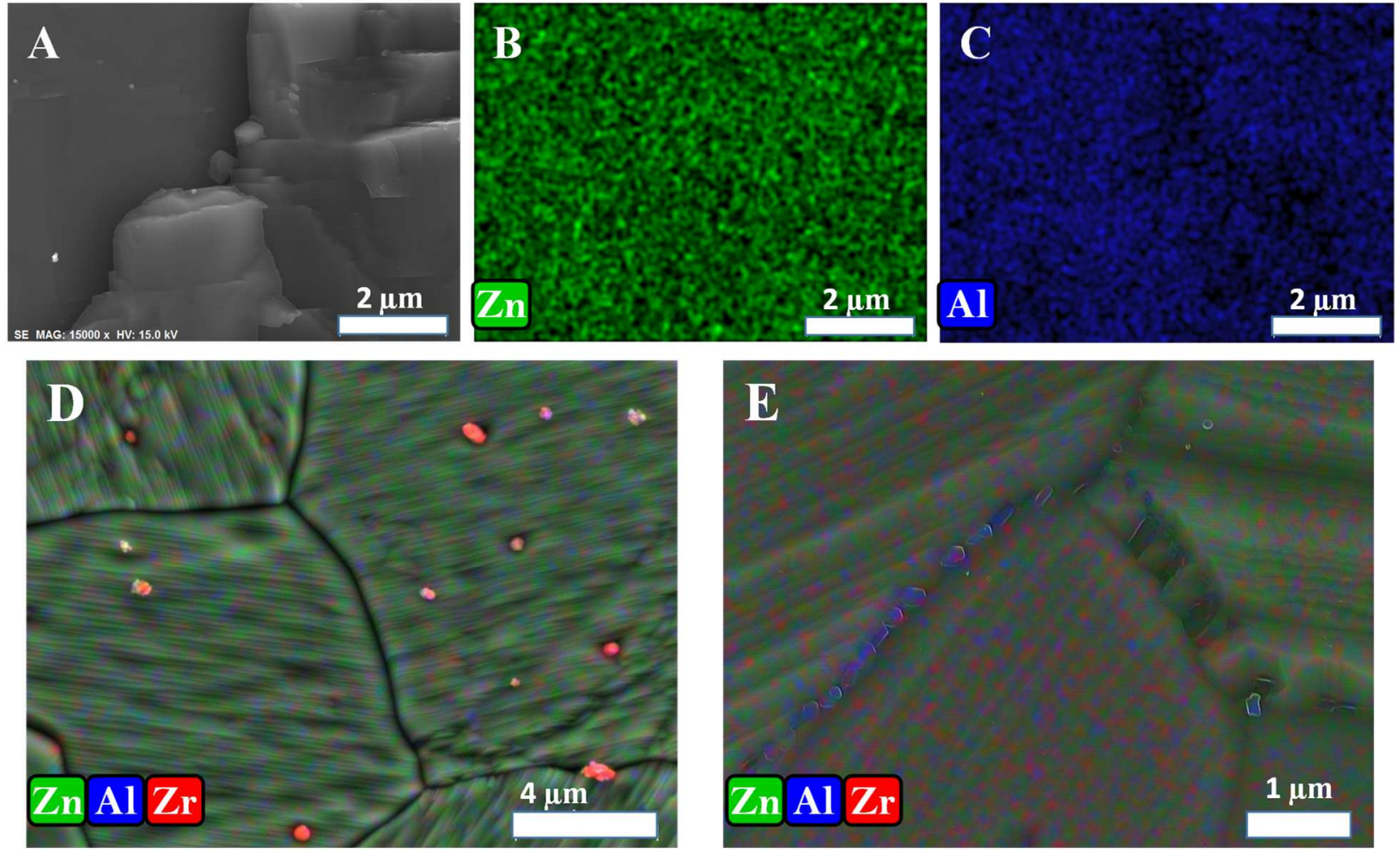
Fig. 3. SEM image (A) and elemental EDS maps (B,C) for the fractured $\mathrm{Zn}_{0.997} \mathrm{Al}_{0.003} \mathrm{O}$ sample, and EDS maps for the polished $\mathrm{Zn}_{0.993} \mathrm{Zr}_{0.007} \mathrm{O}(\mathrm{D})$ and $\mathrm{Zn}_{0.993} \mathrm{Al}_{0.005} \mathrm{Zr}_{0.002} \mathrm{O}(\mathrm{E})$ samples.

Zirconia inclusions are clearly identified for $\mathrm{Zn}_{0.993} \mathrm{Zr}_{0.007} \mathrm{O}$ (Fig. 3D); hence, actual zirconium doping level attained under applied processing conditions is well below $0.7 \%$. A smaller amount of excess zirconia particles was also observed in the $\mathrm{Zn}_{0.993} \mathrm{Al}_{0.002} \mathrm{Zr}_{0.005} \mathrm{O}$ sample. On the contrary, no $\mathrm{ZrO}_{2}$ impurities were identified for $\mathrm{Zn}_{0.993} \mathrm{Al}_{0.005} \mathrm{Zr}_{0.002} \mathrm{O}$, while the separation of residual amounts of aluminum-enriched nanophase containing zinc was observed at the grain boundaries (Fig. 3E). Taking into account the typical reactions occurring in aluminum-doped zinc oxide $[11,38,39]$, one can identify the nanophase as $\mathrm{ZnAl}_{2} \mathrm{O}_{4}$ spinel. Similarly, the presence of only vestigial amounts of $\mathrm{ZnAl}_{2} \mathrm{O}_{4}$ and $\mathrm{ZrO}_{2}$ (not shown) were found in the $\mathrm{Zn}_{0.993} \mathrm{Al}_{0.007} \mathrm{O}$ and $\mathrm{Zn}_{0.994} \mathrm{Al}_{0.003} \mathrm{Zr}_{0.003} \mathrm{O}$ samples by EDS, implying that their actual composition is essentially close to the nominal. It should be noticed that the solubility limits for both aluminum and zirconium in wurtzite structure may vary significantly depending on the processing approaches (bulk ceramics, thin films, nanoparticles) and conditions [10-12,24,26,32,33]. However, detailed structural studies rather suggest that it is well below $1 \%$ at., provided by steric, electronic and natural coordination preferences of zinc and these substituting cations [25,34].

The results of combined electrical studies of $\mathrm{Zn}_{1-\mathrm{x}-\mathrm{y}} \mathrm{Al}_{\mathrm{x}} \mathrm{Zr}_{\mathrm{y}} \mathrm{O}$ ceramics are shown in Fig. 4. 


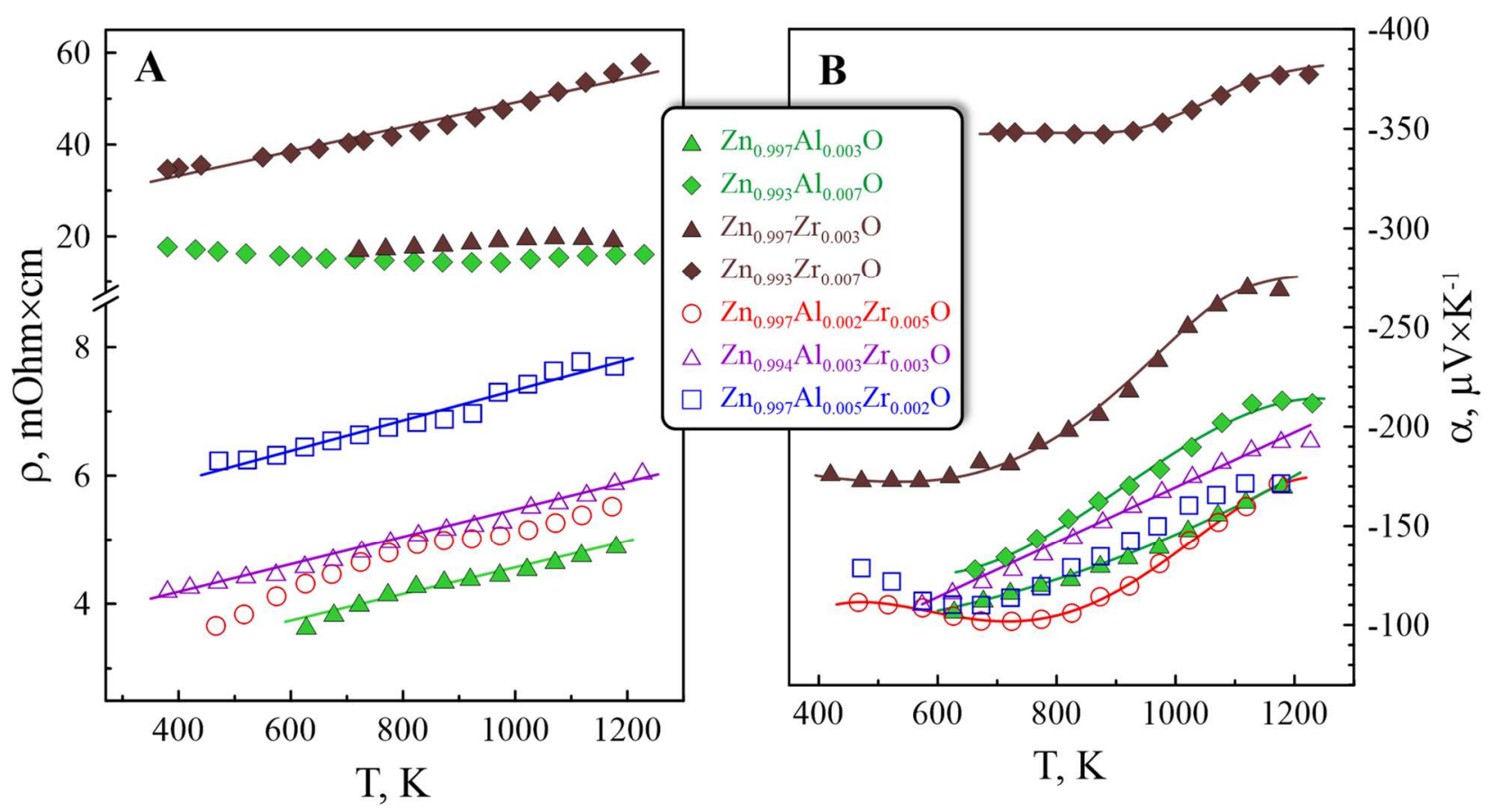

Fig. 4. Temperature dependence of the resistivity (A) and Seebeck coefficient (B).

The values of electrical resistivity obtained for all doped materials (Fig. 4A) are fairly below than for nominally pure $\mathrm{ZnO}(0.35 \mathrm{Ohm} \times \mathrm{cm}$ at $576 \mathrm{~K}$ and $0.25 \mathrm{Ohm} \times \mathrm{cm}$ at $1223 \mathrm{~K})$, used as a precursor for the doped samples and sintered as a reference under identical conditions. This obviously confirms the dissolution of both aluminum and zirconium cations acting as a donor dopants and providing n-type electronic transport, as directly follows from the negative values of the Seebeck coefficient (Fig. 4B). All samples demonstrate a typical degenerate semiconductor behavior with the weak temperature dependence of the relatively low resistivity. All mixed-doped compositions and $\mathrm{Zn}_{0.997} \mathrm{Al}_{0.003} \mathrm{O}$ show an almost linear increase in resistivity on heating, in accordance with Bloch-Grüneisen model for typical metals [40,41], indicating predominant scattering of the charge carriers by the phonons. Indeed, the values of Debye temperature reported for undoped zinc oxide correspond to 400-440 K [42,43], while doping is expected to shift it to lower temperatures [41]. Among the studied materials the lowest resistivity is observed for $\mathrm{Zn}_{0.997} \mathrm{Al}_{0.003} \mathrm{O}$ composition. Although the values of the lattice parameters apparently suggest a similar level of $\mathrm{Al}^{3+}$ for $\mathrm{Zn}^{2+}$ substitution in wurtzite structure (Table 1), $\mathrm{Zn}_{0.993} \mathrm{Al}_{0.007} \mathrm{O}$ sample demonstrates $~ 5$-times higher 
resistivity and a weaker temperature dependence than $\mathrm{Zn}_{0.997} \mathrm{Al}_{0.003} \mathrm{O}$, an evidence for more complex charge carrier scattering mechanism, likely involving an impurity scattering. Somewhat similar dependence of the electrical transport on composition is also observed for $\mathrm{Zn}_{0.997} \mathrm{Zr}_{0.003} \mathrm{O}$ and $\mathrm{Zn}_{0.993} \mathrm{Zr}_{0.007} \mathrm{O}$ samples, containing $\mathrm{ZrO}_{2}$ traces. These samples demonstrate even higher resistivity values than for Al-containing analogues. Taking into account that two free electrons are expected to be produced by $\mathrm{Zr}^{4+}$ for $\mathrm{Zn}^{2+}$ substitution as compared to one electron from $\mathrm{Al}^{3+}$ substitution, one might conclude that under discussed processing conditions the solubility of zirconium cations in wurtzite lattice is significantly below that for aluminum. The observed trends of the resistivity behaviour with temperature agree well with the changes in the Seebeck coefficient (Fig. 4B), which is notably higher for $\mathrm{Zr}$-containing samples.

Surprisingly, the mixed-doped $\mathrm{Zn}_{0.993} \mathrm{Al}_{0.005} \mathrm{Zr}_{0.002} \mathrm{O}, \quad \mathrm{Zn}_{0.994} \mathrm{Al}_{0.003} \mathrm{Zr}_{0.003} \mathrm{O}$ and $\mathrm{Zn}_{0.993} \mathrm{Al}_{0.002} \mathrm{Zr}_{0.005} \mathrm{O}$ samples with the overall nominal doping level of $0.6-0.7 \%$ at. show the resistivity values significantly below that for single Al-doped and $\mathrm{Zr}$-doped materials with similar dopant content. The resistivities of $\mathrm{Zn}_{0.994} \mathrm{Al}_{0.003} \mathrm{Zr}_{0.003} \mathrm{O}$ and $\mathrm{Zn}_{0.993} \mathrm{Al}_{0.002} \mathrm{Zr}_{0.005} \mathrm{O}$ samples are almost reaching those of $\mathrm{Zn}_{0.997} \mathrm{Al}_{0.003} \mathrm{O}$ sample. One should notice that no phase impurities were detected in $\mathrm{Zn}_{0.997} \mathrm{Al}_{0.003} \mathrm{O}$ by structural and microstructural studies, thus suggesting predominant $\mathrm{Al}^{3+}$ for $\mathrm{Zn}^{2+}$ substitution in wurtzite structure. This synergy towards the improvement of the charge transport in Al- and Zr- mixed-doped materials is somewhat not yet well-understood. Based on the structural studies and extracted unit cell sizes, a plausible explanation may rely on the actual increase of the solubility of $\mathrm{Al}^{3+}$ and possibly $\mathrm{Zr}^{4+}$ cations in wurtzite lattice, provided by their simultaneous presence. In particular, a smaller wurtzite unit cell for $\mathrm{Zn}_{0.993} \mathrm{Al}_{0.005} \mathrm{Zr}_{0.002} \mathrm{O}$ as compared to both $\mathrm{Zn}_{0.997} \mathrm{Al}_{0.003} \mathrm{O}$ and $\mathrm{Zn}_{0.993} \mathrm{Al}_{0.007} \mathrm{O}$ may indicate an increased solubility of $\mathrm{Al}^{3+}$ cations, having a smaller size compared to $\mathrm{Zn}^{2+}$. However, the latter is not sufficient to explain a low unit cell volume of the $\mathrm{Zn}_{0.993} \mathrm{Al}_{0.002} \mathrm{Zr}_{0.005} \mathrm{O}$ composition. In such mixed-doped materials, one might expect a complex interplay between substitutions in the lattice and interstitial sites, affected 
by mutual effects provided by the charge and size differences of $\mathrm{Al}^{3+}$ and $\mathrm{Zr}^{4+}$ cations. Presence of even minor phase impurities may decrease the charge carrier mobility; this may account for the slightly higher resistivity of mixed-doped samples as compared to $\mathrm{Zn}_{0.997} \mathrm{Al}_{0.003} \mathrm{O}$, while the corresponding Seebeck coefficients are essentially comparable. Still, the slightly higher Seebeck coefficient of the $\mathrm{Zn}_{0.994} \mathrm{Al}_{0.003} \mathrm{Zr}_{0.003} \mathrm{O}$ is responsible for the highest power factor, observed for this composition (Fig. 5). The mixed-doped $\mathrm{Zn}_{0.993} \mathrm{Al}_{0.002} \mathrm{Zr}_{0.005} \mathrm{O}$ sample also demonstrates a relatively high power factor while containing a significant amount of zirconium, reaching 530 $\mu \mathrm{W} \times \mathrm{m}^{-1} \times \mathrm{K}^{-1}$ at $1173 \mathrm{~K}$.



Fig. 5. Temperature dependence of the power factor.

More insights into the co-doping effects are provided by the DRS. The corresponding results and representative examples of the band gap calculations are described in Annex 1 of the Supplementary Material. The calculated band gap values (Table 1) show a noticeable blueshift for 
the doped materials as compared to the undoped $\mathrm{ZnO}$. In "pure" $\mathrm{ZnO}$ the optical band gap corresponds to the energy difference between conduction and valence band edges. In the doped zinc oxide the donor electrons occupy the bottom of the conduction band and block the low-energy transitions; the latter is known as Burstein-Moss effect which results in widening the optical band gap. These results are consistent with the literature data on Al-doped zinc oxide $[38,44,45]$. The contribution of the Burstein-Moss effect $\left(\Delta E_{B M}\right)$ to the optical band gap can be represented as [46]:

$$
\Delta E_{B M}=\frac{h^{2}}{8 m^{*}} \times\left(\frac{3 n}{\pi}\right)^{2 / 3}
$$

where $h$ is the Planck's constant, $m^{*}$ and $n$ are effective mass and concentration of the charge carriers. The difference of optical band gaps between $\mathrm{Zn}_{0.997} \mathrm{Al}_{0.003} \mathrm{O}, \mathrm{Zn}_{0.993} \mathrm{Al}_{0.002} \mathrm{Zr}_{0.005} \mathrm{O}$ and $\mathrm{Zn}_{0.993} \mathrm{Al}_{0.005} \mathrm{Zr}_{0.002} \mathrm{O}$ is insignificant; the latter suggests similar charge carrier concentrations in these materials. Surprisingly lower value of $E_{g}$ observed for $\mathrm{Zn}_{0.994} \mathrm{Al}_{0.003} \mathrm{Zr}_{0.003} \mathrm{O}$ apparently indicates approaching the Mott critical density of the charge carriers, when an increased contribution of the band gap narrowing mechanisms is competing with the Burstein-Moss effect. This behaviour is often observed in the heavily-doped $\mathrm{ZnO}$ and is associated with various manybody effects on the conduction and valence bands $[44,47]$. In other words, the DRS data suggests that the donor-doping level in $\mathrm{Zn}_{0.994} \mathrm{Al}_{0.003} \mathrm{Zr}_{0.003} \mathrm{O}$, containing an equal amount of both dopants, may be the highest among the mixed-doped samples. Still, no additional conclusions on the mutual solubility effects provided by zirconium and aluminium can be taken from the DRS results due to the presence of minor impurity phases affecting the actual chemical composition of the wurtzite phase. As a hypothesis, slightly lower electrical resistivity of $\mathrm{Zn}_{0.993} \mathrm{Al}_{0.002} \mathrm{Zr}_{0.005} \mathrm{O}$ (Fig. 4A) may be likely attributed to the higher electron mobility, notwithstanding the evidence of phase impurities in this material (Fig. 2).

While co-doping with aluminum and zirconium is shown to provide significant synergistic boosting effects on the electrical conductivity, as discussed above, the long-term stability of $\mathrm{ZnO}$ based thermoelectrics under elevated temperatures still remains one of the main concerns limiting 
the potential applications. The ageing behaviour of selected prepared materials was evaluated at 973K and $1173 \mathrm{~K}$, the results are shown in Fig. 6.
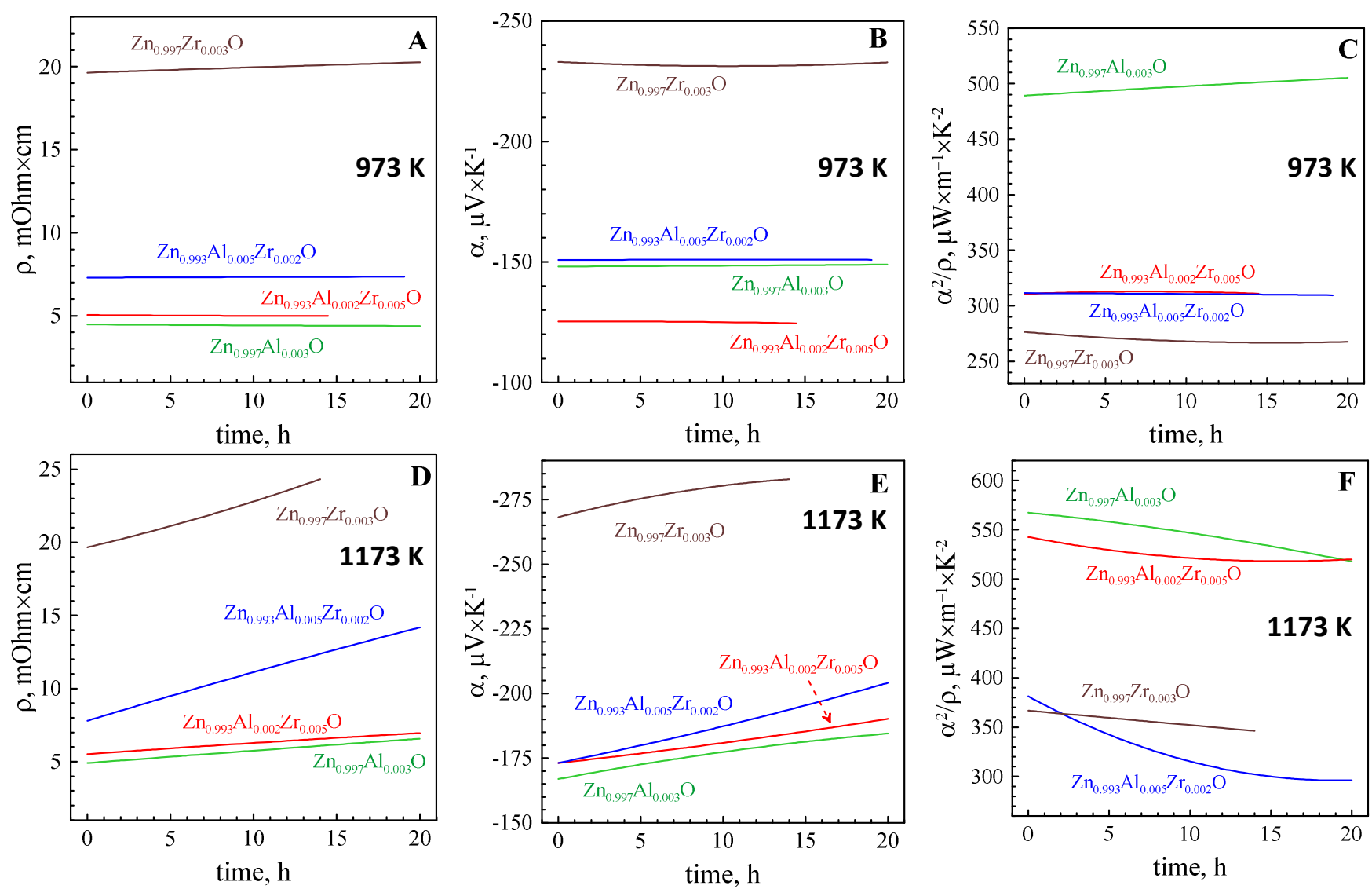

Fig. 6. Time dependencies of the electrical resistivity (A,D), Seebeck coefficent (B,E) and power factor $(\mathrm{C}, \mathrm{F})$ at $973 \mathrm{~K}(\mathrm{~A}, \mathrm{~B}, \mathrm{C})$ and $1173 \mathrm{~K}(\mathrm{D}, \mathrm{E}, \mathrm{F})$.

The essentially stable electrical performance was observed at $973 \mathrm{~K}$ at least during first 20 hours (Fig. $6 \mathrm{~A}, \mathrm{~B}, \mathrm{C}$ ), indicating that this temperature may be still acceptable for the hot side of thermoelectric modules involving the discussed compositions. Higher temperatures result in increase of both electrical resistivity (Fig. 6D) and Seebeck coefficient (Fig. 6E), likely due to a gradual decrease of charge carrier concentration on exsolution of the dopant cations at high temperatures. It should be noticed, however, that corresponding changes in the power factor are rather moderate and tend to stabilize with time for co-doped $\mathrm{Zn}_{0.993} \mathrm{Al}_{0.002} \mathrm{Zr}_{0.005} \mathrm{O}$ and 
$\mathrm{Zn}_{0.993} \mathrm{Al}_{0.005} \mathrm{Zr}_{0.002} \mathrm{O}$, in opposite to the continuous decrease observed for single-doped $\mathrm{Zn}_{0.997} \mathrm{Al}_{0.003} \mathrm{O}$ and $\mathrm{Zn}_{0.997} \mathrm{Zr}_{0.003} \mathrm{O}$ (Fig. 6F). Additional studies are required to corroborate and explain this behavior, which may represent an interesting pathway to $\mathrm{ZnO}$-based thermoelectrics with stable performance.

Yet another great concern regarding the application of donor-doped zinc oxide as thermoelectric material is only slightly addressed by the described co-doping approach. In general, mixed doping is favorable for decreasing the lattice thermal transport due to local changes in density and elastic constants, associated with the different atoms [48]. Fig. 7 shows the temperature dependence of the total (A) and lattice (B) thermal conductivity, calculated from the WiedemannFranz' law as:

$$
\kappa_{p h}=\kappa-L T / \rho
$$

where $L\left(2.45 \cdot 10^{-8} \mathrm{~W} \times \Omega \times \mathrm{K}^{-2}\right)$ is the Sommerfeld value of the Lorenz number [49].
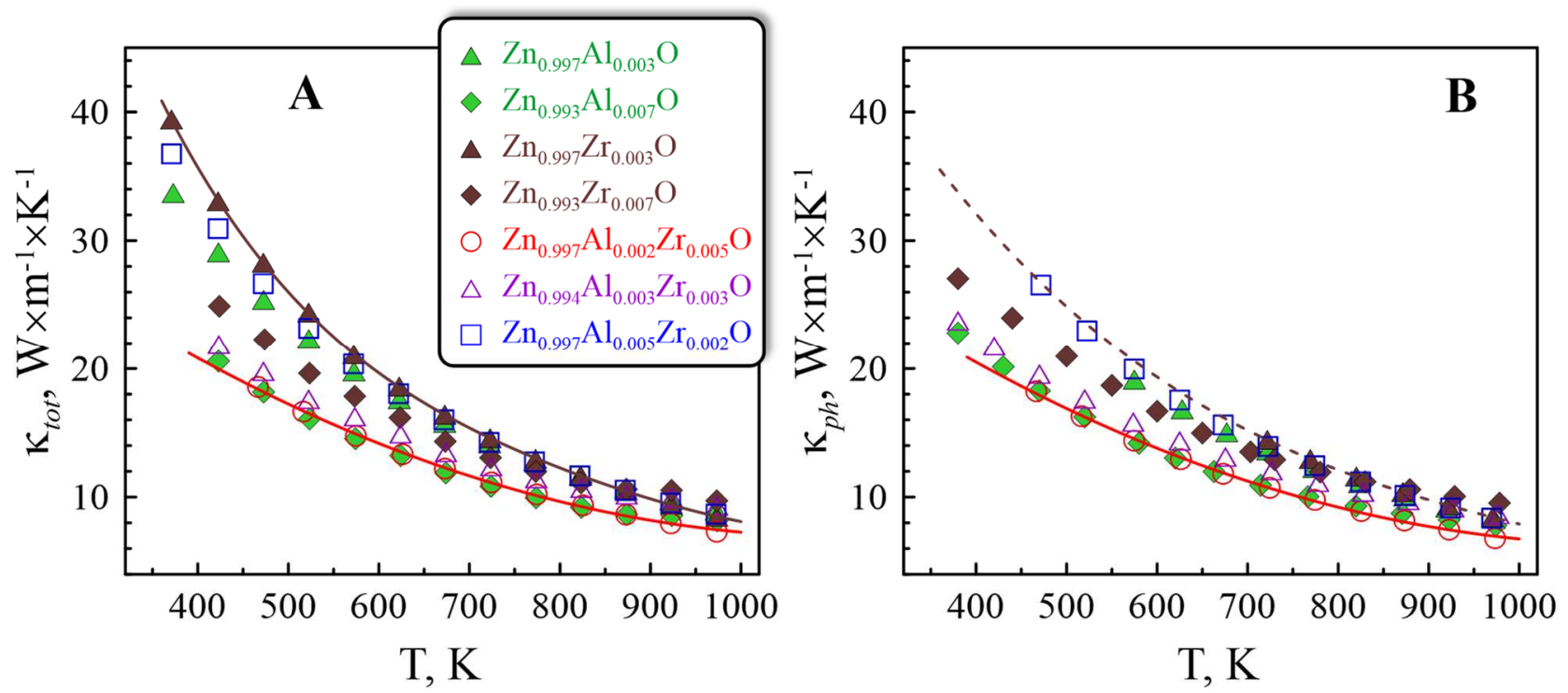

Fig. 7. Temperature dependence of the total (A) and lattice thermal conductivity (B). The dashed line shows the values calculated by extrapolation of the resistivity data to low temperatures.

As for the case of electrical resistivity, the experimental data on thermal conductivity was normalized to $100 \%$ density using the Maxwell correction [12,37]. The contribution of the lattice 
counterpart in the studied materials varies between $88-99 \%$. Thus, the thermal transport is dominated by the phonons and both $\kappa$ and $\kappa_{p h}$ show similar behavior with the composition, converging at high temperatures where phonon scattering mostly occurs through the Umklapp process. The difference in lattice thermal conductivities between the samples becomes larger at lower temperatures, where the phonon mean path is relatively large and scattering at the point defects and phase impurities presents a larger contribution. The relaxation time for point defects scattering $\left(\tau_{P D}^{-1}\right)$ can be represented as below [50,51]:

$$
\tau_{P D}^{-1}=\frac{V \omega^{4}}{4 \pi v_{p}^{2} v_{g}}\left(\sum_{i} f_{i}\left(1-\frac{m_{i}}{\bar{m}}\right)^{2}+\sum_{i} f_{i}\left(1-\frac{r_{i}}{\bar{r}}\right)^{2}\right)
$$

where $V$ is the volume per atom, $\omega$ is the phonon frequency, $v_{p}$ and $v_{g}$ are the phonon phase and group velocities, $f_{\mathrm{i}}$ is the fraction of atoms with mass $m_{i}$ and radius $r_{i}$, residing on a site with average mass and radius $\bar{m}$ and $\bar{r}$. Lower relaxation time is favorable for decreasing the thermal conductivity. Whatever the contribution of the weight and size terms, it turns out that the main obstacle for decreasing the thermal conductivity of $\mathrm{ZnO}$ through doping/substitution is represented by limited solubility of the dopant cations, resulting in very low $f_{i}$ values. The lowest lattice thermal conductivities are demonstrated by the mixed-doped compositions (Fig. 7A,B) and $\mathrm{Zn}_{0.993} \mathrm{Al}_{0.007} \mathrm{O}$ with the highest doping level. On the other hand, the lower solubility of zirconium in $\mathrm{ZnO}$ leads to the higher thermal conductivity of the $\mathrm{Zn}_{0.997} \mathrm{Zr}_{0.003} \mathrm{O}$ and $\mathrm{Zn}_{0.993} \mathrm{Zr}_{0.007} \mathrm{O}$ samples. It should be noticed, however, that the presence of phase impurities as those shown in Fig. 3D,E may contribute to suppressing the thermal transport by additional phonon scattering at the corresponding interfaces. Still, the doping level and mixed doping itself produce rather noticeable effects on the thermal transport, as evidenced by the relatively high thermal conductivity of $\mathrm{Zn}_{0.993} \mathrm{Zr}_{0.007} \mathrm{O}$, containing the highest fraction of secondary phase. 
Finally, Fig. 8 summarizes the relevant effects and shows a cumulative impact of the electrical and thermal properties on the thermoelectric performance of the prepared materials, represented by $Z T$.

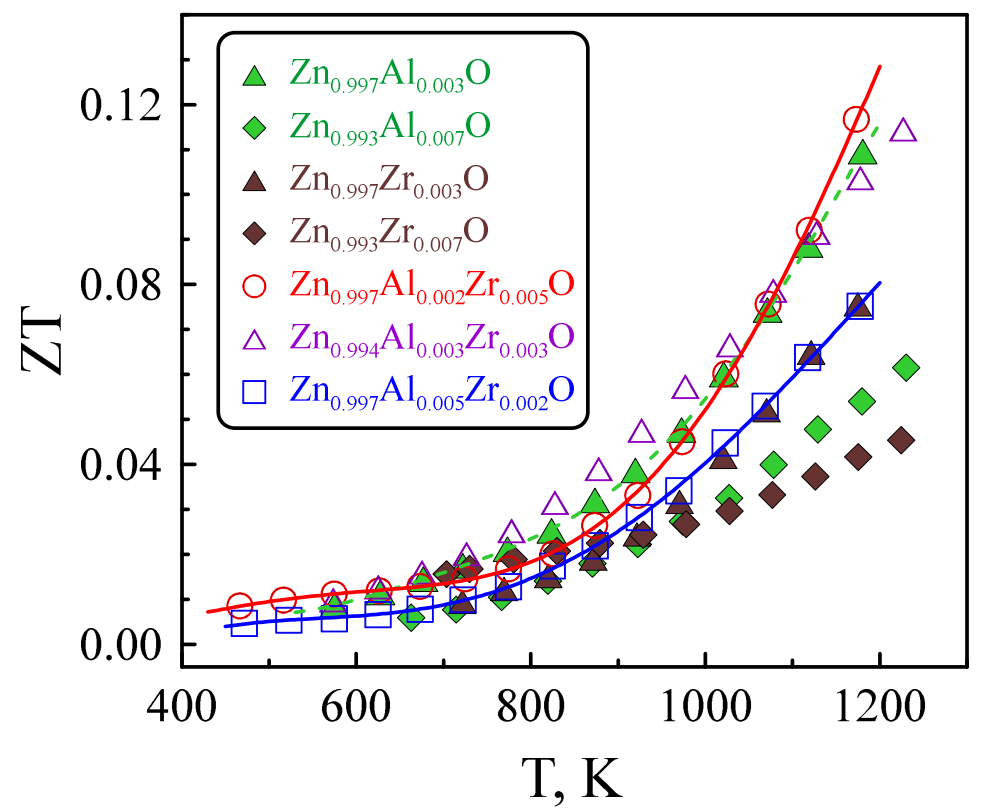

Fig. 8. Temperature dependence of the dimensionless figure-of-merit $Z T$.

The highest $Z T$ s at $\mathrm{T}>900 \mathrm{~K}$ are observed for $\mathrm{Zn}_{0.997} \mathrm{Al}_{0.003} \mathrm{O}$, mixed-doped $\mathrm{Zn}_{0.993} \mathrm{Al}_{0.002} \mathrm{Zr}_{0.005} \mathrm{O}$ and $\mathrm{Zn}_{0.993} \mathrm{Al}_{0.003} \mathrm{Zr}_{0.003} \mathrm{O}$. At $1173 \mathrm{~K}$ the average $Z T$ values of these mixed-doped materials are up to $\sim 2.3$ times exceeding the corresponding average value for single-doped $\mathrm{Zn}_{0.993} \mathrm{Al}_{0.007} \mathrm{O}$ and $\mathrm{Zn}_{0.993} \mathrm{Zr}_{0.007} \mathrm{O}$, possessing roughly the same nominal substitution level. The latter clearly underlines the presence of synergistic effects provided by simultaneous aluminum- and zirconium co-doping, which significantly boosts the thermoelectric performance. Although $\mathrm{Zn}_{0.993} \mathrm{Zr}_{0.007} \mathrm{O}$ actually demonstrates the lowest performance (Fig. 8), it appears that higher content of zirconium in mixed-doped compositions is surprisingly favorable for higher $Z T$, as illustrated by the difference in performances of $\mathrm{Zn}_{0.993} \mathrm{Al}_{0.002} \mathrm{Zr}_{0.005} \mathrm{O}$ and $\mathrm{Zn}_{0.993} \mathrm{Al}_{0.003} \mathrm{Zr}_{0.003} \mathrm{O}$ compared to $\mathrm{Zn}_{0.993} \mathrm{Al}_{0.005} \mathrm{Zr}_{0.002} \mathrm{O}$. This synergy mostly originates from enhanced electronic transport in $\mathrm{Zn}(\mathrm{Al}, \mathrm{Zr}) \mathrm{O}$, as evidenced by the results shown in Fig. 4A, while the variations of the Seebeck 
coefficient and thermal conductivity on co-doping present rather minor contribution. It is believed that further significant enhancement of the thermoelectric performance of mixed-doped compositions is possible only by applying nanostructuring approaches similar to those implemented in recent works (e.g., [27,52,53]), having a major objective to suppress extremely high thermal conductivity of zinc oxide.

\section{Conclusions}

In order to demonstrate the effects of zirconium doping on the thermoelectric performance of bulk $\mathrm{ZnO}$-based thermoelectrics, a set of single-doped and mixed-doped samples with nominal composition $\mathrm{Zn}_{1-\mathrm{x}-\mathrm{y}} \mathrm{Al}_{\mathrm{x}} \mathrm{Zr}_{\mathrm{y}} \mathrm{O}(\mathrm{x}=0-0.007, \mathrm{y}=0-0.007)$ was prepared via conventional solid state route. Electrical studies revealed significantly lower resistivity of $\mathrm{Zn}_{0.993} \mathrm{Al}_{0.005} \mathrm{Zr}_{0.002} \mathrm{O}$, $\mathrm{Zn}_{0.994} \mathrm{Al}_{0.003} \mathrm{Zr}_{0.003} \mathrm{O}$ and $\mathrm{Zn}_{0.993} \mathrm{Al}_{0.002} \mathrm{Zr}_{0.005} \mathrm{O}$ samples as compared to single Al-doped and $\mathrm{Zr}$ doped materials with similar dopant content. The guidelines obtained from variations in unit cell size and optical band gap values suggested an actual increase of the solubility of $\mathrm{Al}^{3+}$ and, possibly, $\mathrm{Zr}^{4+}$ cations in the wurtzite lattice, facilitated by their simultaneous presence. The prepared compositions demonstrated a stable electrical performance at $973 \mathrm{~K}$ for 20 hours. At $1173 \mathrm{~K}$ a noticeable increase in the electrical resistivity and Seebeck coefficient was observed leading to the degradation of the power factor, which was less pronounced for mixed-doped compositions. The lowest lattice thermal conductivities were observed for $\mathrm{Zn}_{0.994} \mathrm{Al}_{0.003} \mathrm{Zr}_{0.003} \mathrm{O}, \mathrm{Zn}_{0.993} \mathrm{Al}_{0.002} \mathrm{Zr}_{0.005} \mathrm{O}$ and $\mathrm{Zn}_{0.993} \mathrm{Al}_{0.007} \mathrm{O}$. Higher content of zirconium in mixed-doped compositions is favorable for higher $Z T$ reaching up to 0.12 at $1173 \mathrm{~K}$.

\section{Supplementary Material}


Supplementary material related to this article can be found, in the online version

\section{Acknowledgements}

This work was supported by the FCT, including individual grant IF/00302/2012, project CICECO-Aveiro Institute of Materials (ref. UID/CTM/50011/2013), project of bilateral cooperation between FCT and DAAD (Germany) and the project POCI-01-0145-FEDER-031875, financed by COMPETE 2020 Program and National Funds through the FCT/MEC and when applicable co-financed by FEDER under the PT2020 Partnership Agreement.

\section{Data availability statement}

The raw/processed data required to reproduce these findings cannot be shared at this time as the data also forms part of an ongoing study. 


\section{References}

[1] T.M. Tritt, Thermoelectric Phenomena, Materials, and Applications, Annu. Rev. Mater. Res. 41 (2011) 433448. doi:10.1146/annurev-matsci-062910-100453.

[2] A. Date, A. Date, C. Dixon, A. Akbarzadeh, Progress of thermoelectric power generation systems: Prospect for small to medium scale power generation, Renew. Sustain. Energy Rev. 33 (2014) 371-381. doi:10.1016/j.rser.2014.01.081.

[3] J. Karni, Solar energy: The thermoelectric alternative, Nat. Mater. 10 (2011) 481-482. doi:10.1038/nmat3057.

[4] M. Backhaus-Ricoult, J. Rustad, L. Moore, C. Smith, J. Brown, Semiconducting large bandgap oxides as potential thermoelectric materials for high-temperature power generation?, Appl. Phys. A Mater. Sci. Process. 116 (2014) 433-470. doi:10.1007/s00339-014-8515-z.

[5] I. Terasaki, Y. Sasago, K. Uchinokura, Large thermoelectric power in NaCo2O4 single crystals, Phys. Rev. B. 56 (1997) R12685-R12687. doi:10.1103/PhysRevB.56.R12685.

[6] S. Hébert, D. Berthebaud, R. Daou, Y. Bréard, D. Pelloquin, E. Guilmeau, F. Gascoin, O. Lebedev, A. Maignan, Searching for new thermoelectric materials: Some examples among oxides, sulfides and selenides, J. Phys. Condens. Matter. 28 (2015) 013001. doi:10.1088/0953-8984/28/1/013001.

[7] J. He, Y. Liu, R. Funahashi, Oxide thermoelectrics: The challenges, progress, and outlook, J. Mater. Res. 26 (2011) 1762-1772. doi:10.1557/jmr.2011.108.

[8] H. Morkoç, Ü. Özgür, Zinc Oxide: Fundamentals, Materials and Device Technology, Wiley-VCH Verlag GmbH \& Co. KGaA, Weinheim, Germany, Germany, 2009. doi:10.1002/9783527623945.

[9] Ü. Özgür, Y.I. Alivov, C. Liu, A. Teke, M.A. Reshchikov, S. Doğan, V. Avrutin, S.J. Cho, H. Morkọ, A comprehensive review of $\mathrm{ZnO}$ materials and devices, J. Appl. Phys. 98 (2005) 1-103. doi:10.1063/1.1992666.

[10] T. Tsubota, M. Ohtaki, K. Eguchi, H. Arai, Thermoelectric properties of Al-doped ZnO as a promising oxide material for high-temperature thermoelectric conversion, J. Mater. Chem. 7 (1997) 85-90. doi:10.1039/a602506d.

[11] M. Ohtaki, T. Tsubota, K. Eguchi, H. Arai, High-temperature thermoelectric properties of (Zn1-xAlx)O, J. Appl. Phys. 79 (1996) 1816-1818. doi:10.1063/1.360976.

[12] L. Zhang, T. Tosho, N. Okinaka, T. Akiyama, Thermoelectric Properties of Solution Combustion Synthesized Al-Doped ZnO, Mater. Trans. 49 (2008) 2868-2874. doi:10.2320/matertrans.MAW200801. 
[13] N. Vogel-Schäuble, Y.E. Romanyuk, S. Yoon, K.J. Saji, S. Populoh, S. Pokrant, M.H. Aguirre, A. Weidenkaff, Thermoelectric properties of nanostructured Al-substituted $\mathrm{ZnO}$ thin films, Thin Solid Films. 520 (2012) 6869-6875. doi:10.1016/j.tsf.2012.07.046.

[14] L.M. Wang, C.Y. Chang, S.T. Yeh, S.W. Chen, Z.A. Peng, S.C. Bair, D.S. Lee, F.C. Liao, Y.K. Kuo, Synthesis and post-annealing effects on the transport properties of thermoelectric oxide (ZnO)mIn2O3ceramics, Ceram. Int. 38 (2012) 1167-1174. doi:10.1016/j.ceramint.2011.06.068.

[15] P. Jood, R.J. Mehta, Y. Zhang, T. Borca-Tasciuc, S.X. Dou, D.J. Singh, G. Ramanath, Heavy element doping for enhancing thermoelectric properties of nanostructured zinc oxide, RSC Adv. 4 (2014) 6363. doi:10.1039/c3ra46813e.

[16] E.M. Hopper, Q. Zhu, J.H. Song, H. Peng, A.J. Freeman, T.O. Mason, Electronic and thermoelectric analysis of phases in the In2O3(ZnO)ksystem, J. Appl. Phys. 109 (2011) 013713. doi:10.1063/1.3530733.

[17] X. Liang, Thermoelectric transport properties of Fe-enriched ZNO with high-temperature nanostructure refinement, ACS Appl. Mater. Interfaces. 7 (2015) 7927-7937. doi:10.1021/am509050a.

[18] H. Colder, E. Guilmeau, C. Harnois, S. Marinel, R. Retoux, E. Savary, Preparation of Ni-doped ZnO ceramics for thermoelectric applications, J. Eur. Ceram. Soc. 31 (2011) 2957-2963. doi:10.1016/j.jeurceramsoc.2011.07.006.

[19] K. Park, J.W. Choi, S.J. Kim, G.H. Kim, Y.S. Cho, Zn1-xBixO $(0 \leq x \leq 0.02)$ for thermoelectric power generations, J. Alloys Compd. 485 (2009) 532-537. doi:10.1016/j.jallcom.2009.06.021.

[20] M. Ohtaki, K. Araki, K. Yamamoto, High thermoelectric performance of dually doped ZnO ceramics, J. Electron. Mater. 38 (2009) 1234-1238. doi:10.1007/s11664-009-0816-1.

[21] K.H. Kim, S.H. Shim, K.B. Shim, K. Niihara, J. Hojo, Microstructural and thermoelectric characteristics of zinc oxide-based thermoelectric materials fabricated using a spark plasma sintering process, J. Am. Ceram. Soc. 88 (2005) 628-632. doi:10.1111/j.1551-2916.2005.00131.x.

[22] D.B. Zhang, B.P. Zhang, D.S. Ye, Y.C. Liu, S. Li, Enhanced Al/Ni co-doping and power factor in textured $\mathrm{ZnO}$ thermoelectric ceramics prepared by hydrothermal synthesis and spark plasma sintering, J. Alloys Compd. 656 (2016) 784-792. doi:10.1016/j.jallcom.2015.10.062.

[23] H. Yamaguchi, Y. Chonan, M. Oda, T. Komiyama, T. Aoyama, S. Sugiyama, Thermoelectric properties of ZnO ceramics Co-doped with $\mathrm{Al}$ and transition metals, J. Electron. Mater. 40 (2011) 723-727. doi:10.1007/s11664-011-1529-9.

[24] V. Gokulakrishnan, S. Parthiban, K. Jeganathan, K. Ramamurthi, Investigation on the effect of Zr doping in 
ZnO thin films by spray pyrolysis, Appl. Surf. Sci. 257 (2011) 9068-9072. doi:10.1016/j.apsusc.2011.05.102.

[25] H. Bian, S. Ma, G. Yang, H. Zhu, X. Xu, S. Yan, J. Gao, Z. Zhang, The optical and electrical properties of ZnO:Zr films, J. Alloys Compd. 672 (2016) 20-26. doi:10.1016/j.jallcom.2016.02.178.

[26] M. Lv, X. Xiu, Z. Pang, Y. Dai, L. Ye, C. Cheng, S. Han, Structural, electrical and optical properties of zirconium-doped zinc oxide films prepared by radio frequency magnetron sputtering, Thin Solid Films. 516 (2008) 2017-2021. doi:10.1016/j.tsf.2007.06.173.

[27] L. Han, D. V. Christensen, A. Bhowmik, S.B. Simonsen, L.T. Hung, E. Abdellahi, Y.Z. Chen, N. V. Nong, S. Linderoth, N. Pryds, Scandium-doped zinc cadmium oxide as a new stable n-type oxide thermoelectric material, J. Mater. Chem. A. 4 (2016) 12221-12231. doi:10.1039/C6TA03126A.

[28] N. Vogel-Schäuble, R. Dujardin, A. Weidenkaff, M.H. Aguirre, Influence of thermal aging phenomena on thermoelectric properties of al-substituted ZnO, J. Electron. Mater. 41 (2012) 1606-1614. doi:10.1007/s11664-011-1851-2.

[29] A.V. Kovalevsky, A.A. Yaremchenko, S. Populoh, A. Weidenkaff, J.R. Frade, Enhancement of thermoelectric performance in strontium titanate by praseodymium substitution, J. Appl. Phys. 113 (2013) 053704. doi:10.1063/1.4790307.

[30] L.J. Brillson, Y. Lu, ZnO Schottky barriers and Ohmic contacts, J. Appl. Phys. 109 (2011) 121301. doi:10.1063/1.3581173.

[31] J. Rodríguez-Carvajal, Recent advances in magnetic structure determination by neutron powder diffraction, Phys. B Condens. Matter. 192 (1993) 55-69. doi:10.1016/0921-4526(93)90108-I.

[32] Y.S. Avadhut, J. Weber, E. Hammarberg, C. Feldmann, J. Schmedt auf der Günne, Structural investigation of aluminium doped $\mathrm{ZnO}$ nanoparticles by solid-state NMR spectroscopy, Phys. Chem. Chem. Phys. 14 (2012) 11610. doi:10.1039/c2cp41139c.

[33] A. Nakrela, N. Benramdane, A. Bouzidi, Z. Kebbab, M. Medles, C. Mathieu, Site location of Al-dopant in $\mathrm{ZnO}$ lattice by exploiting the structural and optical characterisation of $\mathrm{ZnO}$ : Al thin films, Results Phys. 6 (2016) 133-138. doi:10.1016/j.rinp.2016.01.010.

[34] H. Serier, M. Gaudon, M. Ménétrier, Al-doped ZnO powdered materials: Al solubility limit and IR absorption properties, Solid State Sci. 11 (2009) 1192-1197. doi:10.1016/j.solidstatesciences.2009.03.007.

[35] R.D. Shannon, Revised Effective Ionic Radii and Systematic Studies of Interatomie Distances in Halides and Chaleogenides Central Research and Development Department, Experimental Station, E . L Du Pont 
de Nemours The effective ionic radii of Shannon \& Prewitt [ Acta, Acta Cryst. A32 (1976) 751-767. doi:10.1107/S0567739476001551.

[36] N. Clament Sagaya Selvam, J.J. Vijaya, L.J. Kennedy, Effects of morphology and Zr doping on structural, optical, and photocatalytic properties of ZnO nanostructures, Ind. Eng. Chem. Res. 51 (2012) 16333-16345. doi:10.1021/ie3016945.

[37] A.V. Kovalevsky, M.H. Aguirre, S. Populoh, S.G. Patrício, N.M. Ferreira, S.M. Mikhalev, D.P. Fagg, A. Weidenkaff, J. Frade, Designing strontium titanate-based thermoelectrics: an insight into defect chemistry mechanisms, J. Mater. Chem. A. 5 (2017). doi:10.1039/C6TA09860F.

[38] P. Jood, R.J. Mehta, Y. Zhang, G. Peleckis, X. Wang, R.W. Siegel, T. Borca-Tasciuc, S.X. Dou, G. Ramanath, Al-doped zinc oxide nanocomposites with enhanced thermoelectric properties, Nano Lett. 11 (2011) 4337-4342. doi:10.1021/nl202439h.

[39] D. Gautam, M. Engenhorst, C. Schilling, G. Schierning, R. Schmechel, M. Winterer, Thermoelectric properties of pulsed current sintered nanocrystalline Al-doped $\mathrm{ZnO}$ by chemical vapour synthesis, J. Mater. Chem. A. 3 (2015) 189-197. doi:10.1039/C4TA04355C.

[40] N.W. Ashcroft, N.D. Mermin, Solid State Physics, Cengage Learning, 1976.

[41] P. V. Chinta, O. Lozano, P. V. Wadekar, W.C. Hsieh, H.W. Seo, S.W. Yeh, C.H. Liao, L.W. Tu, N.J. Ho, Y.S. Zhang, W.Y. Pang, I. Lo, Q.Y. Chen, W.K. Chu, Evolution of Metallic Conductivity in Epitaxial ZnO Thin Films on Systematic Al Doping, J. Electron. Mater. 46 (2017) 2030-2039. doi:10.1007/s11664-0165117-x.

[42] W.N. Lawless, T.K. Gupta, Thermal properties of pure and varistor $\mathrm{ZnO}$ at low temperatures, J. Appl. Phys. 60 (1986) 607-611. doi:10.1063/1.337455.

[43] R.A. Robie, H.T. Haselton, B.S. Hemingway, Heat capacities and entropies at 298.15 K of MgTiO3(geikielite), ZnO (zincite), and ZnCO3(smithsonite), J. Chem. Thermodyn. 21 (1989) 743-749. doi:10.1016/0021-9614(89)90058-X.

[44] B.E. Sernelius, K.F. Berggren, Z.C. Jin, I. Hamberg, C.G. Granqvist, Band-gap tailoring of ZnO by means of heavy Al doping, Phys. Rev. B. 37 (1988) 10244-10248. doi:10.1103/PhysRevB.37.10244.

[45] W. Zhang, J. Gan, L. Li, Z. Hu, L. Shi, N. Xu, J. Sun, J. Wu, Tailoring of optical and electrical properties of transparent and conductive Al-doped $\mathrm{ZnO}$ films by adjustment of Al concentration, Mater. Sci. Semicond. Process. 74 (2018) 147-153. doi:10.1016/j.mssp.2017.10.028.

[46] A.P. Roth, J.B. Webb, D.F. Williams, Absorption edge shift in $\mathrm{ZnO}$ thin films at high carrier densities, Solid 
State Commun. 39 (1981) 1269-1271. doi:10.1016/0038-1098(81)90224-6.

[47] A. Jain, P. Sagar, R.M. Mehra, Band gap widening and narrowing in moderately and heavily doped n-ZnO films, Solid. State. Electron. 50 (2006) 1420-1424. doi:10.1016/j.sse.2006.07.001.

[48] H.J. Goldsmid, Introduction to Thermoelectricity Theory of Thermoelectric Refrigeration, Springer Berlin Heidelberg, Berlin, Heidelberg, 2012. doi:10.1007/978-3-662-49256-7.

[49] G. V Chester, A. Thellung, The Law of Wiedemann and Franz, Proc. Phys. Soc. 77 (1961) 1005-1013. doi:10.1088/0370-1328/77/5/309.

[50] E.S. Toberer, A. Zevalkink, G.J. Snyder, Phonon engineering through crystal chemistry, J. Mater. Chem. 21 (2011) 15843. doi:10.1039/c1jm11754h.

[51] J.D. Chung, a. J.H. McGaughey, M. Kaviany, Role of Phonon Dispersion in Lattice Thermal Conductivity Modeling, J. Heat Transfer. 126 (2004) 376. doi:10.1115/1.1723469.

[52] L. Han, N. Van Nong, W. Zhang, L.T. Hung, T. Holgate, K. Tashiro, M. Ohtaki, N. Pryds, S. Linderoth, Effects of morphology on the thermoelectric properties of Al-doped ZnO, R. Soc. Chem. Adv. 4 (2014) 12353. doi:10.1039/c3ra47617k.

[53] D.-B. Zhang, H.-Z. Li, B.-P. Zhang, D. Liang, M. Xia, Hybrid-structured ZnO thermoelectric materials with high carrier mobility and reduced thermal conductivity, RSC Adv. 7 (2017) 10855-10864. doi:10.1039/C6RA28854E. 